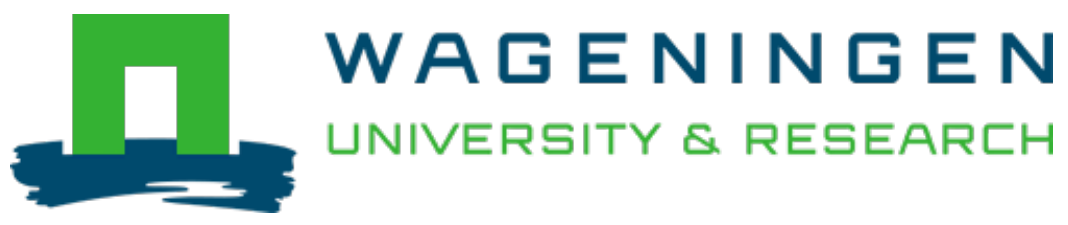

\title{
Soaking of maize determines the quality of aflata for kenkey production.
}

\author{
Journal of Cereal Science
}

Nche, P.F.; Odamtten, G.T.; Nout, M.J.R.; Rombouts, F.M.

https://doi.org/10.1006/jcrs.1996.0061

This publication is made publicly available in the institutional repository of Wageningen University and Research, under the terms of article $25 \mathrm{fa}$ of the Dutch Copyright Act, also known as the Amendment Taverne. This has been done with explicit consent by the author.

Article $25 \mathrm{fa}$ states that the author of a short scientific work funded either wholly or partially by Dutch public funds is entitled to make that work publicly available for no consideration following a reasonable period of time after the work was first published, provided that clear reference is made to the source of the first publication of the work.

This publication is distributed under The Association of Universities in the Netherlands (VSNU) 'Article $25 \mathrm{fa}$ implementation' project. In this project research outputs of researchers employed by Dutch Universities that comply with the legal requirements of Article $25 \mathrm{fa}$ of the Dutch Copyright Act are distributed online and free of cost or other barriers in institutional repositories. Research outputs are distributed six months after their first online publication in the original published version and with proper attribution to the source of the original publication.

You are permitted to download and use the publication for personal purposes. All rights remain with the author(s) and / or copyright owner(s) of this work. Any use of the publication or parts of it other than authorised under article $25 \mathrm{fa}$ of the Dutch Copyright act is prohibited. Wageningen University \& Research and the author(s) of this publication shall not be held responsible or liable for any damages resulting from your (re)use of this publication.

For questions regarding the public availability of this publication please contact openscience.library@,wur.nl 


\title{
Soaking of Maize Determines the Q uality of A flata for Kenkey Production
}

\author{
P. F. N che*, G. T. O damttent, M. J. R. N out* $\ddagger$ and F. M. Rombouts* \\ *Department of Food Science, Agricultural University, Bomenweg 2, 6703 HD W ageningen, \\ The $N$ etherlands, †Department of Botany, University of G hana, P.O. Box 55, Legon/ Accra, G hana
}

Received 12 A ugust 1994; revised version received 9 April 1995

\begin{abstract}
A BSTRACT
A flata is a gelatinised maize paste, serving as intermediate in the manufacture of kenkey, a traditional cooked fermented maize product of $\mathrm{G}$ hana. The effect of water uptake during soaking of whole or dry-milled maize, the extent of starch damage, dough $\mathrm{pH}$, fermentation time, and of endogenous and added enzymes on pasting and set-back viscosities of aflata dough were studied. Water uptake by coarsely dry-milled maize (grits) reached $0.63 \mathrm{~mL} / \mathrm{g}$ dry matter in just $1 \mathrm{~h}$, compared with $0.50 \mathrm{~mL} / \mathrm{g}$ in 3 days for whole grain. $\mathrm{H}$ igh endogenous activity of proteases and carbohydrases were recorded in both grits and whole maize when soaked at $4^{\circ} \mathrm{C}$ or $25^{\circ} \mathrm{C}$. These were significantly reduced after soaking at $60^{\circ} \mathrm{C}$. Soaking of grits at $60^{\circ} \mathrm{C}$ with a heat-stable protease, or wet fine-milling of fermented grits resulted in significant $(P<0.05)$ increases in pasting viscosities. Peak viscosities increased with fermentation time up to $24 \mathrm{~h}$. Pasting viscosities decreased with repeated wet milling of fermented dough.

(c) 1996 Academic Press Limited
\end{abstract}

Keywords: aflata, kenkey, maize, dry-milling, wet-milling, viscosity.

\section{IN TRO DUCTIO N}

K enkey, a popular $\mathrm{G}$ hanaian staple is produced from fermented maize dough. During traditional kenkey production ${ }^{1,2}$, whole maize is soaked for 1-2 days at ambient temperature $\left(25-30^{\circ} \mathrm{C}\right)$, milled and made into a dough (moisture content approx. $500 \mathrm{~g} / \mathrm{kg}$ dry matter), which is then allowed to ferment naturally at ambient temperature for several days. Part of the fermented dough (usually half) is mixed with water to give a slurry with a dry matter content of $250 \mathrm{~g} / \mathrm{kg}$, and cooked to gelatinisation to give a thick and sticky paste, called the aflata. This paste is then mixed with the uncooked portion of the dough and serves as a binding agent ${ }^{3}$ as well as moisturiser. When kneaded together, the aflata holds the uncooked dough together into a dumpling which can then be shaped, wrapped and boiled to give kenkey.

‡T o whom correspondence should be addressed.
The whole process is tedious and can take up to 6 days to complete.

A dough with a high starch gelatinisation index ${ }^{3}$ (during cooking) and a high set-back viscosity, on cooling, is required to give an aflata of adequate binding and moisturising capacity. This is very important in determining the desired textural characteristics of cooked kenkey, which is a cohesive mass of coarse particulate matter cemented by the aflata. Good kenkey is neither too sticky nor crumbly. The choice of ingredients and the pretreatment of maize and dough for aflata production are, therefore, crucial to the achievement of these properties. Local women kenkey producers prefer maize with a high swelling index.

In an attempt to reduce process time, it was suggested earlier ${ }^{4,5}$ to omit the soaking stage and substitute it with a lactic starter-fermentation of a suspension of dry-milled flour. In addition, household-scale kenkey making could be made less tedious by supplying a mix containing dehydrated fermented flour and dehydrated, pre-gelatinised 
aflata. It has, however, been reported that significant starch damage in dry-milled maize resulted in a dough of very low pasting and set-back viscosities ${ }^{6}$, although poor release of starch during dry milling would also be an important factor. Soaking of maize, on the other hand, is known to facilitate smooth milling ${ }^{7}$, and is also considered crucial to the production of dough with high pasting and set-back viscosities ${ }^{5}$ necessary for making aflata with the desired binding potential. Soaking usually takes $24-48 \mathrm{~h}$, and omission or shortening of this step would be desirable if production time is to be reduced for the purpose of industrial-scale kenkey manufacture. $\mathrm{H}$ owever, given the importance of soaking, it is necessary to understand which changes occur during this step and how they affect the desirable properties of aflata. These changes may be (bio)chemical (enzymatic, pH, acidity), microbiological (microbial proliferation) or physical (water uptake). The aim of this work is to investigate the individual and/ or collective roles of such changes in determining the quality of aflata for kenkey production.

\section{MATERIALS AND METHODS}

Dry local white maize (Z ea mays L CV. O bataanba) was supplied by the Crops R esearch Institute, C SIR, K wadaso, Ghana. This is a cultivar commonly used by traditional kenkey makers and had been stored dry at $-20^{\circ} \mathrm{C}$ in our laboratory prior to being used.

\section{Cleaning, disinfection and soaking of whole maize}

Whole maize kernels were first rinsed $(2 \times 2 \mathrm{~min})$ with sterile distilled water and then disinfected for $5 \mathrm{~min}$ at ambient temperature with a $10 \mathrm{~g} / \mathrm{L}$ solution of sodium hypochlorite. Treated kernels were then rinsed $(2 \times 2 \mathrm{~min})$ with sterile distilled water before soaking in sterile distilled water at $4{ }^{\circ} \mathrm{C}$ or $25^{\circ} \mathrm{C}$ for $72 \mathrm{~h}$. Untreated maize soaked under the same conditions served as a control. Samples of steep water were analysed on a daily basis for microbial load. Sampling, dilution and enumeration of total aerobic mesophilic bacteria, lactic acid bacteria (LAB), Enterobacteriaceae and fungi were as described earlier ${ }^{8}$.

$$
\text { Dry-milling }
$$

D ry maize kernels were coarsely milled in a hammer mill (F ritsch Pulverisette T ype 14.702, M arius
Instruments, U trecht, The Netherlands) using a 12 tooth rotor and a $4 \mathrm{~mm}$ screen to obtain grits. $\mathrm{R}$ otor speed was set at $20000 \mathrm{rpm}$.

\section{W et-milling}

Soaked maize kernels were first coarsely milled using a 12 tooth rotor and a $4 \mathrm{~mm}$ screen. Subsequently, a 24 tooth rotor was used in combination with either a $1 \mathrm{~mm}$ or $0.5 \mathrm{~mm}$ screen for fine-milling of fermented dough from coarsely milled grits. Rotor speed was maintained at $20000 \mathrm{rpm}$.

Endogenous enzyme activity in dry and soaked maize

M aize samples were soaked at $4{ }^{\circ} \mathrm{C}, 25^{\circ} \mathrm{C}$ and $60^{\circ} \mathrm{C}$. Dry milled maize (DM) was used as a standard and the test samples were either dry maize milled before soaking (D M S) or whole maize soaked before milling (WM S). API-ZYM kits (API Products, M ontalieu, V ercieu, France) were used according to the manufacturer's instructions to evaluate endogenous enzyme activities of dry and soaked maize. The enzymes tested included: phosphatases (alkaline, acid, naphthol-A S-BI-phosphohydrolase); esterases (C 4, C 8, C 14); peptidases (leucine-, valine-, and cystine arylamidases); carbohydrases ( $\alpha$-galactosidase, $\beta$-galactosidase, $\beta$-glucuronidase, $\alpha$-glucosidase, $\beta$-glucosidase, $\mathrm{N}$-acetyl- $\beta$-glucosiminidase, $\alpha$-mannosidase, $\alpha$ fucosidase). Aliquots of $65 \mu \mathrm{L}$ 1:10 maize suspension in distilled water $(\mathrm{pH} \mathrm{5)}$ were incubated at $37^{\circ} \mathrm{C}$ for $4 \mathrm{~h}$ after which the enzyme activity was estimated visually using a standard API-ZYM colour chart. This was on a scale of $0-5$ indicating the amount of substrate hydrolysed by the enzymes; where 0, 1, 2, 3, 4, 5 represented $0,5,10$, 20,30 and $\geq 40$ nmoles of degraded substrate, respectively.

\section{Water uptake}

Pre-weighed $(100 \mathrm{~g})$ whole kernels were soaked in $300 \mathrm{ml}$ of distilled water at $4{ }^{\circ} \mathrm{C}$ and $25^{\circ} \mathrm{C}$ for 12 , 24,48 and $72 \mathrm{~h}$, after which the water was drained and the weight increase measured as water uptake. Samples were taken of dry milled maize grits soaked under similar conditions as above for 1,2 , 4, 6 and $8 \mathrm{~h}$, weighed and then dried for $48 \mathrm{~h}$ in a hot air oven maintained at $80^{\circ} \mathrm{C}$ to determine 
their moisture contents. Water uptake was determined by subtracting the moisture content of maize flour from that of an equivalent amount of soaked grits.

\section{Viscosity of maize dough}

A Brabender $V$ isco-A mylograph was used to measure the pasting characteristics of variously treated maize doughs. D ough suspensions containing $90 \mathrm{~g}$ dry matter/ $L$ distilled water were used and conditions were as described earlier ${ }^{4}$.

\section{Treatment with proteolytic enzyme}

Some $(45 \mathrm{~g})$ of the dry-milled maize was also soaked at $25^{\circ} \mathrm{C}$ and $60^{\circ} \mathrm{C}$ in $500 \mathrm{~mL}$ of distilled water containing $5 \mathrm{~mL}$ of a mixture of heat-stable acid, neutral and alkaline bacterial proteases (Protease-L 660 , Solvay Enzymes, $\mathrm{H}$ annover) to determine the effects of proteolytic enzyme activity on the pasting characteristics of the resulting dough.

\section{Effect of $\mathrm{pH}$ on pasting characteristics}

G rits were slurried $(90 \mathrm{~g} / \mathrm{L}$ in distilled water) and $\mathrm{pH}$ adjusted prior to gelatinisation with $1 \mathrm{~m} \mathrm{HCl}$ to 6.0 (representing the initial $\mathrm{pH}$ of dry-milled maize), 5.6 (representing the $\mathrm{pH}$ of wet-milled maize) and 3.6 (representing the $\mathrm{pH}$ of a 3 days' fermented dough). The pasting viscosity of each slurry was determined using a Brabender $V$ iscoA mylograph as described above ${ }^{4}$.

\section{Fermentation time}

G rits (100 g) were made into a dough by adding $80 \mathrm{~mL}$ of distilled water, and the dough fermented by an accelerated natural process ${ }^{4}$, which required an inoculation of fresh dough with a $L A B$-enriched starter dough prepared as described by $\mathrm{N}$ out et al. ${ }^{9}$. Fermentation was carried out at $30^{\circ} \mathrm{C}$ for 0 , $4,8,12$ and $24 \mathrm{~h}$. At the end of each fermentation period, the dough was milled to pass through a $1 \mathrm{~mm}$ sieve, and slurried in distilled water as described above. The slurry was adjusted to $\mathrm{pH}$ 6.0 with $1 \mathrm{~m} \mathrm{NaOH}$ to eliminate $\mathrm{pH}$ effects before measuring the pasting characteristics of the dough.

\section{RESULTS AND DISCUSSIO N}

D uring soaking of whole maize at $4{ }^{\circ} \mathrm{C}$ and $25^{\circ} \mathrm{C}$ increases of total aerobic counts in soak water, observed after $48 \mathrm{~h}$ incubation, reached levels of $>10^{5} \mathrm{cfu} / \mathrm{mL}$ in non-disinfected samples. On the other hand, a solution of sodium hypochlorite $(10 \mathrm{~g} / \mathrm{L})$ was very effective in keeping the microbial load of disinfected kernels below $10^{4} \mathrm{cfu} / \mathrm{mL}$, and was subsequently used in cases requiring kernel disinfection.

W ater uptake at $4{ }^{\circ} \mathrm{C}$ and $25^{\circ} \mathrm{C}$ by soaked whole kernels reached $0.42 \mathrm{~mL} / \mathrm{g}$ dry matter after $24 \mathrm{~h}$, and $0.50 \mathrm{~mL} / \mathrm{g}$ after $72 \mathrm{~h}$ of soaking. Water uptake was faster when the maize was coarsely milled before soaking, reaching $0.63 \mathrm{~mL} / \mathrm{g}$ dry matter after $1 \mathrm{~h}$ of soaking.

A high endogenous enzyme activity was recorded in both dry and soaked maize at $4^{\circ} \mathrm{C}$ and $25^{\circ} \mathrm{C}$ (Fig. 1). Following soaking at $4^{\circ} \mathrm{C}$ and $25^{\circ} \mathrm{C}, \alpha$-galactosidase and $\alpha$-mannosidase were stimulated. $\beta$-galactosidase, $\alpha$ - and $\beta$-glucosidase, $\mathrm{N}$-acetyl- $\beta$-glucosaminidase, leucine arylamidase and valine arylamidase activities remained unchanged, whilst cystine arylamidase, trypsin and chymotrypsin were suppressed. W ith the exception of $\beta$-galactosidase and $\alpha$-mannosidase, all peptidases and carbohydrases were suppressed following soaking at $60^{\circ} \mathrm{C}$.

D ry-milling resulted in a dough with very low pasting and set-back viscosities (Fig. 2), confirming earlier reports ${ }^{6,7}$ that ogi flour from dry-milled maize has very poor pasting properties. Soaking of grits at $60^{\circ} \mathrm{C}$ also did not improve on the low pasting and set-back viscosities. The gelatinisation temperature (estimated as the temperature at which viscosity increase starts on a $\mathrm{V}$ isco-Amylogram) was $85^{\circ} \mathrm{C}$ and no peak was obtained during the heating phase, suggesting incomplete swelling of granules and incomplete gelatinisation ${ }^{10}$.

When a heat-stable proteolytic enzyme was added to soaking grits at $60^{\circ} \mathrm{C}$, it resulted in significantly higher pasting and set-back viscosities (Fig. 2). The index of gelatinisation, peak viscosity and set-back viscosity of 610 B.U ., 1325 B.U . and 1260 B.U . respectively, were comparable to those reported for traditional fermented maize dough ${ }^{5}$ and ogi from soaked maize ${ }^{6}$. The gelatinisation temperature was also reduced from $85^{\circ} \mathrm{C}$ to $73^{\circ} \mathrm{C}$. Soaking of grits with protease at $25^{\circ} \mathrm{C}$, on the other hand, further reduced the pasting and setback viscosities of the resulting dough (Fig. 2). D ry-milling has been reported ${ }^{6}$ to cause high levels of mechanical starch damage, making any exposed starch granules susceptible to attack by either endogenous amylolytic enzymes or hydrolytic enzymes of fermenting microorganisms? ${ }^{7}$ T he result 


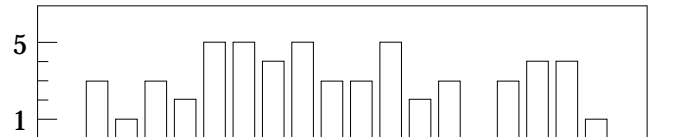

DM
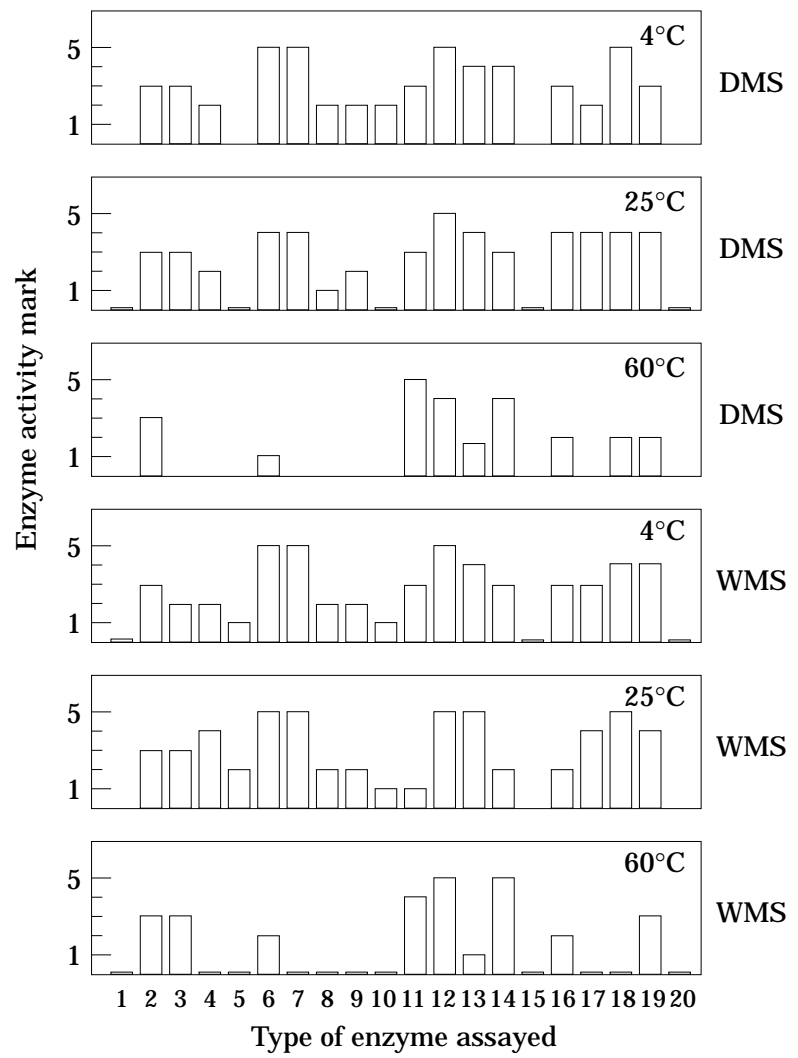

Figure 1 Endogenous enzyme profiles of soaked and dry maize as determined with an API-ZYM kit: DM =dry-milled maize; DM S = dry-milled maize soaked for 2 hours; WM S= whole maize soaked for $24 \mathrm{~h}$ before milling. The assayed enzymes are indicated at the bottom by 1-20 where:

$1=$ control; 2 =alkaline phosphatase; $3=$ esterase (C 4$) ; 4=$ esterase lipase (C 8); $5=$ lipase (C 14); $6=$ leucine arylamidase; $7=$ valine arylamidase; $8=$ cystine arylamidase; $9=$ trypsin; $10=$ chymotrypsin; $11=$ acid phosphatase; $12=$ naphthol-AS$\mathrm{BI}$-phosphohydrolase; $13=\alpha$-galactosidase; $14=\beta$-galactosidase; 15 - $\beta$-glucuronidase; $16=\alpha$-glucosidase; $17=\beta$-glucosidase; $18=\mathrm{N}$-acetyl- $\beta$-glucosaminidase; $19=\alpha$-mannosidase; $20=\alpha$-fucosidase.

would be a dough with very much reduced pasting and set-back viscosities as the amount of starch to be gelatinised is significantly reduced.

The effects of endogenous or added proteolytic enzymes on the viscosity of either whole or milled maize during soaking may depend on the composition of the material embedding the starch granules within the endosperm. In the endosperm of wheat grains, for example, starch granules are surrounded by a composite of proteins, minerals

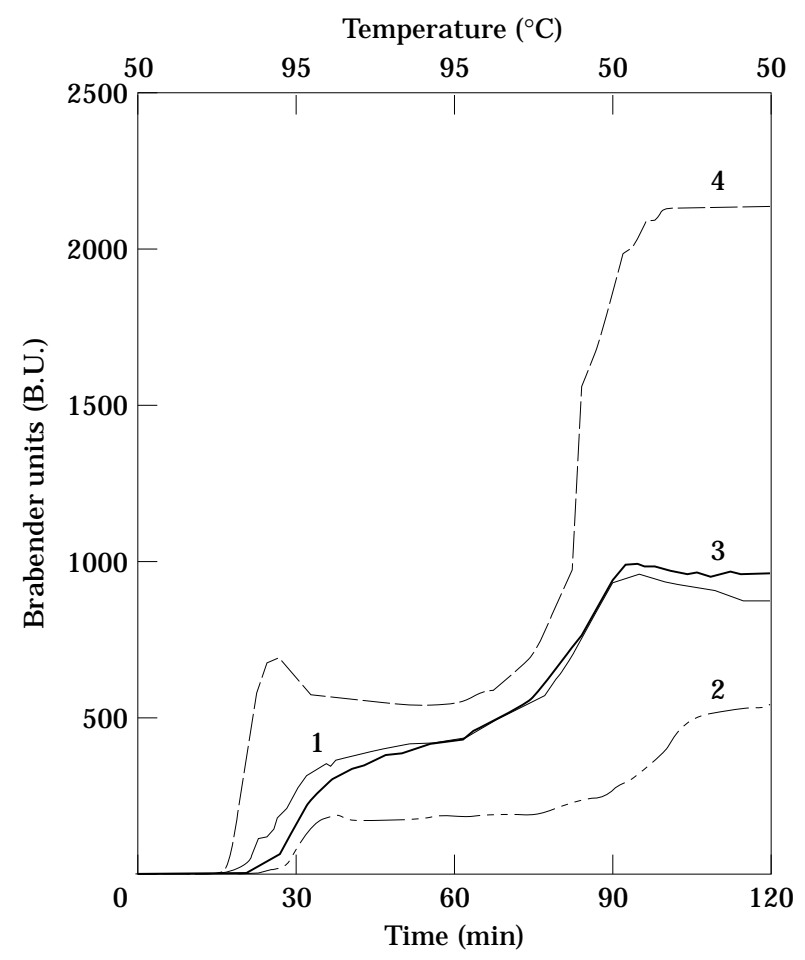

Figure 2 The effect of soaking, with and without protease L-660, on the pasting properties of dry-milled maize grits: $1=$ dry-milled grits + water; $2=$ dry-milled grits soaked for $2 \mathrm{~h}$ at $25^{\circ} \mathrm{C}$ with protease $\mathrm{L}-660 ; 3=$ dry-milled grits soaked for $2 \mathrm{~h}$ at $60^{\circ} \mathrm{C} ; 4=$ dry-milled grits soaked for $2 \mathrm{~h}$ at $60^{\circ} \mathrm{C}$ with protease L-660.

and enzymes ${ }^{11,12}$. Presumably in maize grains, the effect of added or endogenous proteolytic enzymes during soaking will be to break down a similar matrix embedding starch granules, thus allowing them to swell freely and gelatinise faster and better. Addition of the heat-stable proteolytic enzyme, protease L-660, during soaking of dry-milled maize flour at $25^{\circ} \mathrm{C}$, did not affect pasting properties for two possible reasons. First, $25^{\circ} \mathrm{C}$ is not the optimum temperature for this enzyme and, second, some of the damaged or freed starch granules may be hydrolysed by endogenous or microbial enzymes. The use of other proteases with optimum activities at ambient temperatures had a similar effect (data not included) to that obtained with Protease L-660. At $60^{\circ} \mathrm{C}$, however, the activity of protease $L-660$ is highest and the matrix structure holding granules together ${ }^{11,13}$ may be degraded, thus releasing starch granules. Furthermore, at $60^{\circ} \mathrm{C}$, endogenous and microbial carbohydrases are considerably suppressed, hence, very little hydrolysis of damaged or freed starch granules is 


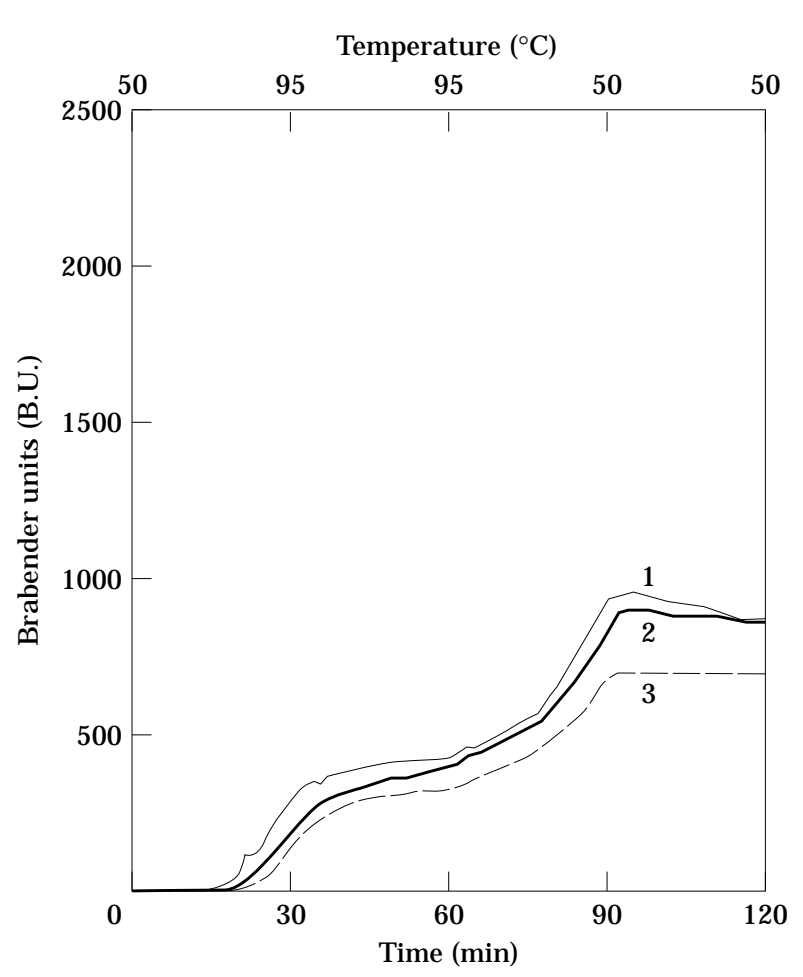

Figure 3 The effect of $\mathrm{pH}$ on the pasting properties of drymilled maize grits: $1=\mathrm{pH} 6 \cdot 0 ; 2=\mathrm{pH} 5 \cdot 6 ; 3=\mathrm{pH} 3 \cdot 6$.

expected to occur. Following such treatment, starch granules may swell freely, when heated, exuding solubilised amylose ${ }^{14}$ that will contribute significantly to an increase in the pasting and setback viscosities of the dough.

Soaking of maize and the subsequent fermentation of dough results in a lowered $\mathrm{pH}$. Figure 3 shows that by lowering the $\mathrm{pH}$ of dry-milled flour, the pasting viscosity of the resulting dough was slightly reduced. In all instances, no peak was obtained during the heating phase, again indicating incomplete gelatinisation and consequently low set-back. This suggests that $\mathrm{pH}$ may be ruled out as a factor contributing to higher gelatinisation viscosity in fermented wet milled maize doughs.

W et fine-milling (to pass through a $1.0 \mathrm{~mm}$ sieve) of fermented dough from grits, however, resulted in a significant increase in pasting viscosity (Fig. 4), suggesting that more intact starch granules were freed by this process.

$V$ isco-A mylograms of doughs fermented for 0 , $4,8,12$ and $24 \mathrm{~h}$, milled to pass through a $1.0 \mathrm{~mm}$ sieve and adjusted to $\mathrm{pH} 6.0$ show increasing

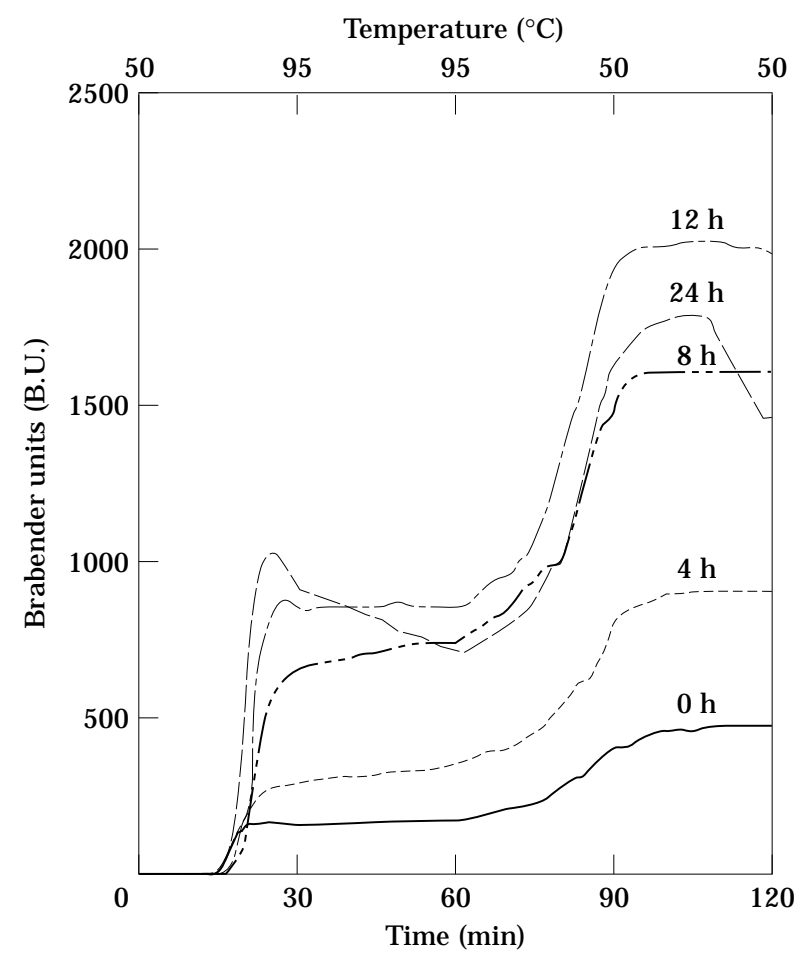

Figure 4 The effect of fermentation time (at $30^{\circ} \mathrm{C}$ ) on the pasting properties of dry-milled maize grits at $0,4,8,12$ and $24 \mathrm{~h}$.

pasting and set-back viscosities (Fig. 4). At 0, 4 and $8 \mathrm{~h}$, no clear peak viscosities were obtained due to incomplete gelatinisation ${ }^{10}$, whereas after 12 and $24 \mathrm{~h}$ of fermentation, peak viscosities were obtained during the heating phase, indicating a higher degree of gelatinisation. Fermentation for $24 \mathrm{~h}$ resulted in a lower gelatinisation temperature, a higher peak viscosity, but a reduced set-back viscosity compared with a $12 \mathrm{~h}$ fermented dough. These observations are in agreement with earlier reports ${ }^{15,6}$ that fermentation of maize flour increases the swelling and thickening potential of the maize starch component. After $24 \mathrm{~h}$ fermentation, the starch component rapidly swells on heating to $95^{\circ} \mathrm{C}$. At temperatures higher than the gelatinisation temperature, some of the swollen starch granules break up and exude their solubilised contents. This explains the dip in viscosity after a peak has been reached. It can be deduced from Figure 4 that $12-24 \mathrm{~h}$ of fermentation of drymilled maize dough would give an acidified dough with adequate pasting characteristics for aflata production; however, such a dough must be wetmilled before cooking to give aflata. 


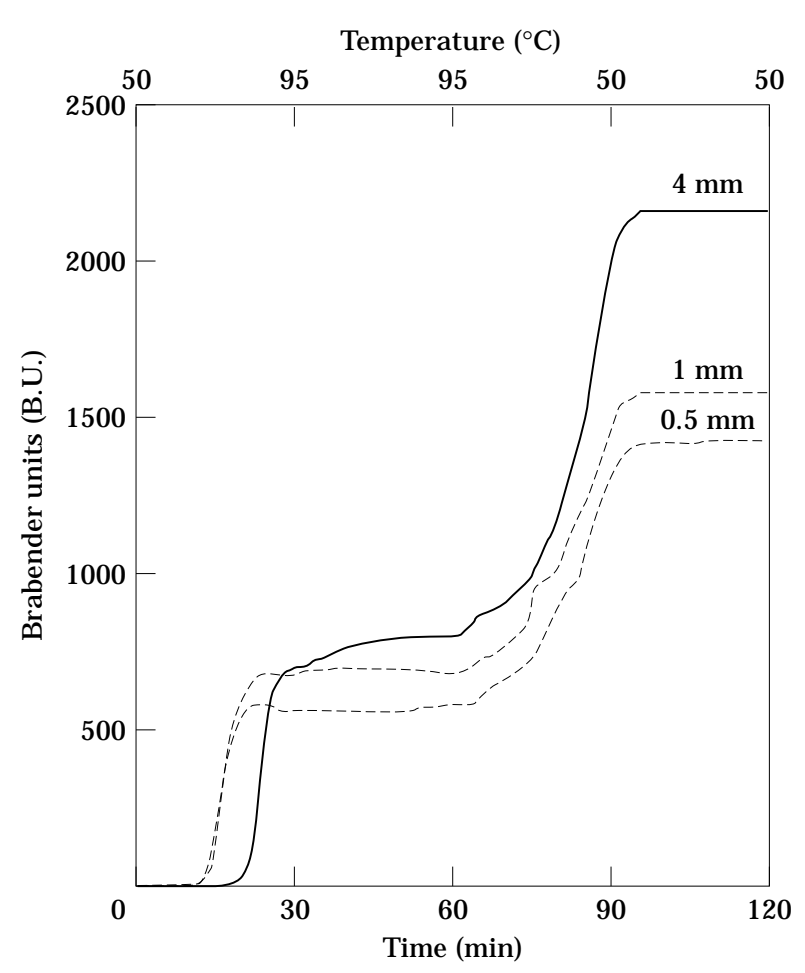

Figure 5 The effect of milling levels $(4 \mathrm{~mm}, 1 \mathrm{~mm}$ and $0.5 \mathrm{~mm}$ ) on the pasting properties of $24 \mathrm{~h}$-fermented (at $30^{\circ} \mathrm{C}$ ) dough from wet-milled maize.

Repeated wet-milling of fermented dough, to pass through $1 \mathrm{~mm}$ and $0.5 \mathrm{~mm}$ sieves (Fig. 5), resulted in doughs with lower pasting and set-back viscosities than dough from coarsely wet-milled (through a $4 \mathrm{~mm}$ sieve) maize. Although not determined here, mechanical starch damage could be one reason for lower viscosities.

$V$ arious factors have been listed as being important in the formation and determination of characteristics of starch gels. A mongst these factors are: the type, size and previous treatment of starch granules, as well as paste concentration, amylose/ amylopectin ratio, and the temperature and time of cooking ${ }^{10}$. R esults presented here confirm that a complex combination of factors during soaking and milling of maize and fermentation of the resulting dough contribute to the final pasting characteristics of kenkey dough. Endogenous enzyme activity, hydration and grain softening during soaking combine to facilitate the release of starch during milling, thus ensuring better hydration and swelling of granules, achieving a high degree of gelatinisation and set-back necessary for good aflata quality.
Acidification of dough from dry-milled maize by accelerated natural fermentation ${ }^{4}$ and wet-milling of the aflata portion may be more acceptable than the use of proteolytic enzymes which would raise production costs and arouse consumer fears, as this could be interpreted in the same light as the addition of chemical substances to a product that has always been considered as natural. Soaking whole maize before milling, however, remains the best option for developing the necessary dough textural characteristics.

\section{A cknowledgements}

This work was carried out in the context of an EC sponsored project (C ontract N o. T S2-0267-UK ; 'T he evaluation and improvement of traditional fermented cereals and legumes in Ghana'), and in collaboration with U nilever Research Laboratorium, Vlaardingen, The N etherlands. We also thank Dr T on van V liet for his valuable comments and suggestions.

\section{REFEREN CES}

1. M uller, H.G . and N yarko-M ensah, B. Studies on kenkey, a Ghanaian cereal food. J ournal of the Science of $F$ ood and A griculture 23 (1972) 544-545.

2. N che, P.F., N out, M .J.R . and R ombouts, F.M . T he effect of cowpea-supplementation on the quality of kenkey, a traditional G hanaian fermented maize food. J ournal of Cereal Science 19 (1994) 191-197.

3. Sefa-Dedeh, S. and Plange, $\mathrm{H}$. Processing of $\mathrm{G}$ a kenkey (komi) in $G$ reater Accra region. A techno-economic study. Kellog International R eport $\mathbf{0 3 / 1 9 8 8 ~ ( 1 9 8 9 ) ~ 1 - 3 6 . ~}$

4. N che, P.F., O damtten, G.T., N out, M.J.R. and R ombouts, F.M. Dry-milling and accelerated fermentation of maize for industrial production of kenkey, a Ghanaian cereal food. J ournal of C ereal Science 20 (1994) 291-298.

5. Bediako-Amoa, B. and A ustin, F.A. Investigation of the aflata process in kenkey manufacture. Ghana J ournal of A griculture and Science 9 (1976) 59-61.

6. A deyemi, I.A. and Beckley, 0 . Effect of period of maize fermentation and souring on chemical properties and amylograph pasting viscosity of ogi. J ournal of $\mathrm{C}$ ereal Science 4 (1986) 353-360.

7. A kingbala, J.O., O nochie, E.U., Adeyemi, I.A. and O guntimein, G.B. Steeping of whole and dry-milled maize kernels in ogi preparation. J ournal of $F$ ood Processing and Preservation $\mathbf{1 1}$ (1987) 1-11.

8. N out, M .J.R ., Beernink, G . and Bonants-van Laarhoven, T.M.G. Growth of Bacillus cereus in soya bean tempeh. International J ournal of Food M icrobiology 4 (1987) 213-301.

9. N out, M .J.R., R ombouts, F.M. and H autvast, G.J. Accelerated natural lactic fermentation of infant food formulations. F ood and Nutrition Bulletin 11 (1989) 65-73.

10. O lkku J. and R ha, C. Gelatinisation of starch and wheat flour starch. F ood C hemistry 3 (1978) 293-317.

11. K night, J.W. Wheat starch and its forms. In 'T he chem- 
istry of wheat starch and gluten'. L eornard H ill, London (1965) pp 40-83.

12. Barlow, K .K ., Buttrose, M.S., Simmonds, D.H . and V esk, $M$. The nature of the starch-protein interface in wheat endosperm. C ereal Chemistry 50 (1973) 443-454.

13. T uschoff, J.V. H ydroxypropylated starches. In 'M odified Starches: Properties and U ses', (O.B. Wurzburg, ed.), CR C Press, Boca R aton, Florida (1987) pp 89-96.
14. Miller, B.S., Derby, R.I. and Trimbo, H.B. A pictoral explanation for the increase in viscosity of a heated wheat starch-water suspension. C ereal C hemistry $\mathbf{5 0}(1972)$ 271-280.

15. Banigo, E.O.I., De M an, J.M. and Duitschaever, C.L. $U$ tilisation of high lysine corn for fermentation of ogi using a new and improved processing system. Cereal Chemistry 51 (1974) 559-572. 